\title{
Implementation of Quick HIV Tests in a Basic Health Unit in the Town of Santa Cruz-RN: Experiment Experienced by the PR0/PET-Saúde Students
}

\author{
Ana Rafaela Dantas dos Santos, Ana Mayara Gomes de Sousa, Fernanda Diniz de Sá, \\ Adriana Gomes Magalhães, Fábia Barbosa de Andrade, Higo Luiz Amorim Belo Maia \\ Faculty of Health Sciences of Trairi (FACISA), Federal University of Rio Grande do Norte (UFRN), Santa Cruz, \\ Brazil \\ Email: anarafaela11@hotmail.com, ana.mayara@yahoo.com.br, fedinizsa@yahoo.com.br, \\ adriana_fsm@yahoo.com.br, fabiabarbosabr@yahoo.com.br, higobelo_hb@hotmail.com
}

Received 11 May 2015; accepted 28 December 2015; published 31 December 2015

Copyright (C) 2015 by authors and Scientific Research Publishing Inc.

This work is licensed under the Creative Commons Attribution International License (CC BY). http://creativecommons.org/licenses/by/4.0/

(c) (i) Open Access

\begin{abstract}
This article is about a report of the experiment of PRO/PET-Saúde students in the anti-HIV tests implementation in the town of Santa Cruz-RN. The goal is to report the importance and discuss the aspects of the moment experienced above inside the basic health unit in the town of Santa Cruz-RN. The experience occurred in the months from February to March 2014 and they were conducted within 8 hours per week. This way, it is observed that the period lived made possible great reflection about the making of the examination in the pre-natal appointment routines, cataloguing challenges which come up during their adequacy within the services. Lastly, the action developed aimed for the aggregation of an active learning process in the search for a critical sense in the experienced practice, allowing and prioritizing the basic health unit as a scope of reference and counter-reference in the public health service, increasing concrete answers and the needs of the population, guaranteeing an adequate service delivery and strengthening the SUS more and more. The insertion of students through the PRO/PET-Saúde-Rede Cegonha enables a reorientation of professional formation, from the integration between service and teaching.
\end{abstract}

\section{Keywords}

Pregnant, Student, Teaching-Service, HIV Tests, Vertical Transmissions 


\section{Introduction}

The Acquired Immunodeficiency Syndrome (AIDS) is a very relevant theme, because it consists in a contemporary Public Health problem which strikes men and women, brings implications to society in their many dimensions, and causes important social impact [1].

AIDS is a very complex epidemic due to its magnitude and extension; in the last 30 years it continues to be one of the biggest world challenges costing more than 35 million lives, presenting itself as the fifth main cause of death between adults, the main cause of death among adults and the main cause of death in women between 15 and 49 years old [2].

Epidemiologic data show that increase in the number of women infected by the virus represented the possibility of vertical transmission (VT) of HIV, which responds currently for over $80 \%$ of the cases of AIDS in children under the age of 13 [3].

This way, in 2007, the Ministry of Health launches the Plano para a Redução da Transmissão Vertical do HIV e da Sífilis no Brasil, in order to contemplate one of the three axes of the Pacto pela Saúde-the Pacto pela Vida. The motherly and child mortality reduction is among its priorities. One of the components for the execution of this priority is the reduction of the Vertical Transmissions (VT) of HIV and syphilis [4].

In Brazil, concerning the number of prevalence of HIV in mothers, the expected number of mothers with HIV is about 12 thousand cases a year. In 2012, only 55\% of the expected cases were notified by the Sistema de Agravos de Notificação (SINAN). The Nordeste region presented the higher percentage of notified cases considering the expected number (64\%); the Sul, 62\%; the Sudeste, 52\%; the Norte, 47\%; and the Centro-Oeste, 43\% [5].

In this context, the ordinance from the Ministry of Health number 1.459 from July 24, 2011 instituted the Rede Cegonha strategy, which is a network of care for assuring women the right to reproductive planning, the humanized attention to pregnancy, labor and puerperium, as well as the right for safe birth, growth and healthy development for the child. Making clear the importance of following-up pregnant women in the three network complexity levels, mainly the basic attention is considered the point of entry in the health services, because it is normally a place that people look for care, especially pregnant women, for pre-natal [1].

Acknowledging the importance of HIV prevention measures on TV in the basic care, the Ministry of Health saw the need for Basic Care teams in performing the quick tests for the HIV diagnosis in the scope of pre-natal care for pregnant women and their sexual partners. These quick exams are inserted in the scope of the pre-natal component of the Rede Cegonha as one of the offers that aim qualifying the mother-child care [3].

Regarding this important strategy in the Ministry of Health, the theses of Rede Cegonha as a research in the Programa Nacional de Reorientação Profissional em Saúde (PRÓ-SAÚDE) and the Programa de Educação pelo Trabalhador para a Saúde (PET-SAÚDE) were created through the ordinance number 6, from April 3rd 2012, which aim to the re-orientation of the professional formation through the teaching-service integration, assuring a complete approach of the health-disease process with emphasis in the basic care, promoting transformations in the teaching and learning processes and then in the aid to the population, fostering tutoring learning groups in the Estratégia de Saúde da Família, becoming an instrument of qualification in the service of professionals, as well as the experience of students who are still in the graduation in health services [6].

The PRÓ-Saúde and the PET-Saúde Rede Cegonha were implemented in the town of Santa Cruz-RN, in partnership with the Universidade Federal do Rio Grande do Norte/Faculdade de Ciências da Saúde do Trairí (UFRN/FACISA), contemplating the courses of Physiotherapy, Nursery and Nutrition. This articulation is allowing the university students a larger approach between teaching, service and the community, offering gradual enrichment towards the academic sector.

The participation in the PRÓ-SAÚDE/PET-SAÚDE (2012 to 2014) in the thesis of the Rede Cegonha was made through the inclusion of scholarship and volunteer students allocated in the health service of basic care in the town of Santa Cruz-RN, to the follow up of the developed activities, as well as strengthening the community-teaching-learning [6]. This way the students allocated in the care services went through many experiences and they were stimulated to meditate over such experiences.

Regarding the situation exposed above, it is realized that it is of great value the implementation of quick HIV tests in the Basic Care units, aiming to diminish the risks and possible harms that the progression of the pathology caused by the virus-AIDS — can cause. With an early diagnosis, the psychological and pharmacological measures can be better evaluated in a way of corroborating to a better quality of life of the patient, as well as, 
diminishing the flow in the hospital scope. Thus, the goal of this article is to report the experience of the participants of the PRO/PET-Saúde in the follow up of the process of quick HIV diagnosis test implementation in pregnant women, inserted in the actions of the Rede Cegonha, which is the project theme.

\section{Experiment Report}

The study reports the experiments of students from PRO/PET-Saúde in the follow up of the implementation of quick HIV tests in a Unidade Básica de Saúde (UBS) from the town of Santa Cruz-RN. The duration of the experiment was of about 2 months, in the months of February and March in 2014, being the activities develop within 8 hours per week.

The students walked in the footsteps of a nursery professional, tutor of the PRÓ/PET-Saúde project, during the pre-natal appointment, where the quick HIV tests were performed. At the beginning the pregnant women went through counseling, where the step about the importance of the realization of the pre-natal test was made, the advisory of women and their sexual partners about their expectations, evaluation of risks and vulnerabilities, as well as ethical matters related to the test realization. After the biological material was collected, blood in this case, because according to the test the used material for analysis may vary in each procedure, after being harvested the blood was inserted in the analysis platform which already comes with the reagents, when analyzed the test provides results in 15 minutes. After these steps, pregnant women were called for post-test guidance and received the results in a quick and practical way, the professional remains guiding and supporting the patient in their decisions after the quick tests.

In order to diminish the Vertical Transmission, the Ministry of Health created the Plano Operacional para Redução de Transmissão Vertical do HIV in which are included the increase of testing coverage in the pre-natal of 52\%, in 2004, to 90\% until December 20011 and the implementation and availability of the quick HIV diagnosis test in places agreed with the state and municipal offices.

The quick tests are used in emergency prophylaxis: the VT prevention of the HIV in patients or pregnant women without anti-HIV tests in the pre-natal or a non-available result; situations of occupational hazard, being the testing made in the zero patient; sexual violence, being the testing made in the violator and for diagnostic purposes.

In the follow up of the quick tests implementation in the town of Santa Cruz, most of the tests were made during the pre-natal appointments, because the kits were already in the Unidades Básicas de Saúde, as well as some emergency situations, where the client required it to the professional, because there was doubt about their exposure to the virus, or even during appointments where there were the identifications, made by the professional, of a possible exposure of the client to the virus. Normally the priority for making the tests is towards pregnant women, with the ends of easing the access to the result of the virus diagnosis, since the results from the conventional serology took too long to arrive.

According to the Ministry of Health [4], it is recommended the offering of the anti-HIV test in all the pregnant women during the pre-natal, in order to make the follow up to the mothers who are carriers of the virus for non-breastfeeding and guidance about feeding the children exposed to the HIV with a child formula, since birth, or with human pasteurized milk, provided by the breast milk bank and the follow up of the mother and the child in special care service (SAE), which is a specialized network to care for pregnant women according to the exam results, connecting the basic attention to a medium and high complexity service.

During our experience no HIV positive cases were identified, however, it was discussed with the tutor nurse about the assistance that a positive patient would have from the town office, in case of a positive result. It was explained that, in such situation, it is asked a second laboratorial test for the confirmation and after a notification about the positive and the Unidade Básica mentions the pregnant woman to the SAE (Serviço de Atendimento Especializado), this service gives support to the follow up to these pregnant women, as well as the forwarding to the maternity hospital which should take precautions and the continuity of the care along with the professionals from the Unidade Básica acting the counter-references to primary care services. Then, after delivery, the medical professional and nurse shall monitor the postpartum consultation, giving the guidelines and continued care to the SAE conducts and motherhood.

Thus, we can highlight the importance of tracking the HIV virus while still in the gestation for the reduction of the vertical transmissions, as well as the implementation of these tests in the Care Units, which are seen as the doorway of the population in the Public Health System. 
With the implementation of the Rede Cegonha, there was a considerable enhancement in the offer for quick HIV tests, which enhanced the diagnosis in the country as the years went by. A study made with pregnant women in 2010/2011 verified that about 99\% of the pregnant women had at least one pre-natal appointment, from this number, $69.9 \%$ had six appointments or more. The coverage for HIV testing in the pre-natal went to 83.5\% in 2010 from $62.3 \%$ in 2006 [5].

Regarding the professions involved in the process of implementing the anti-HIV tests, they must be qualified for their making and for informing the results - be it positive or not. However, such standardization predicts their participation and involvement directly in the actions related to the quick testing and other which possess the necessary capacitation for such activity [7]. This way, the Secretaria de Saúde from Santa Cruz provided courses for this capacitation and realization for all the staff. In its majority the nursery professionals attended the courses and as they were involved in the pre-natal appointments they conducted the tests and tried scheduling them in their routine, because-as we have seen - most of times the problems in making the tests weren't related to the qualification of the staff, but to a schedule problem for making it between appointments, due to a high demand of their service. Yet, as it was possible, we observed that the tests were made. We had the opportunity to live in a special day when the Unidade Básica de Saúde made a task force only for the making of the tests in pregnant women, as well as it happens the making of the tests in the meetings of the Grupo de Gestante, with mothers who weren't tested before.

Paz, Silva e Tavares [7] state that to understand the dilemma of women regarding the HIV infection it is necessary that the nursery professionals who act in the pre-natal and labor assistance enhance the matter of listening and the professional approach as a disease, respecting biological psycho-social aspects. As well as making actions of promotion and prevention, which ease the process of counseling, turned to exams of pregnant women and their partners, in the routine of pre-natal services. The first step, called counseling, is understood as a dialogue based in the relation of trust that aims to provide conditions to the people so they can evaluate their own risks, make decisions and find realistic ways of facing HIV/AIDS related problems. The role of the professional is listening to the individual so one can give him emotional support, proposing questions that ease the awareness and facing of the difficulties by the individual.

This way, during the step of counseling we have seen that the professional always sought to welcome the pregnant woman, in order to create an environment of trust and respect, so she became more receptive and collaborated with the counseling, as she knew that the professional and everybody in the room would secure her data [7]. During the appointment, matters about the disease were discussed, such as virus characteristics, ways of contaminations, the harm imposed by the disease, partner-related factors, if the pregnant woman was exposed to any risk situation and ways of prevention so that she could understand the importance of making the test, as well as making her responsible for her own care.

The capacitated and sensitive professional makes the advising a process of active listening, generating a relation of trust with the pregnant woman, minimizing dilemmas and stressful situations due to the result. The quality of this process enables the professional to evaluate situations of exposure to the risk of HIV infection and other STDs (for the woman and her partner), giving the pregnant woman the opportunity to prepare for receiving an HIV diagnosis or for the adoption of measures of prevention from this infection and other STDs [8].

The tutoring professional that we accompanied during the counseling sought to make dialogues that favored the connection with pregnant woman, this way she became more participative, and this way the professional could evaluate and identify doubts and needs one might had, always taking into account their expectations, risks and vulnerabilities in STDs; guiding and supporting her in her decisions from the quick tests results.

In the post-counseling, the professional must clarify the pregnant woman, parturient, puerperal about the meaning of the testing results and, whatever it may be, inform her about the means of transmitting HIV and other STDs, besides primary prevention measures or re-infection prevention. In this phase, the professional must use a simple language, without judgment and seek to make an evaluation of the mental state of the pregnant woman. Thus, if the result were negative, there must be a conversation about avoiding the HIV virus infection, but if the result were positive, the post-counseling must help the pregnant woman to accept the contamination and understand the risks of transmission, including the vertical one and start the anti-retroviral treatment. Then we can see the importance of giving attention to the health of the pregnant woman, mainly in the making of the quick tests that involve the following phases: counseling before and after testing and the procedure that involves the demanding, making, interpretation and communication of the quick HIV test diagnosis [7].

In our experience we could follow all these phases, however we have realized that due to the demand, the 
professional made the before and after test counseling in a simple and quick way, always respecting the needs for clarifications about the tests, in a way that the patient could understand the process that she was undergoing, and after, the material necessary for the test itself was collected. As to the making and interpretation, the quick test is made in a simple and practical way, lasting 15 minutes, but many times the professional called another pregnant woman for the pre-counseling and after the biological material collection, making an interpretation of the test results from the first patient who was after conducted to the post-counseling, which was also made in a quick way. This way, we have seen that the steps happened according to the standards guidelines, however the professional only could fulfill the steps according to the time one had depending on the demand.

Despite the measures established by the Ministry of Health, there are still flaws when approaching the patients. Only with the involvement of managers and the capacitation of personnel involved in receiving the patients will it be possible the correct guidance of actions that enable the effective HIV vertical transmission prevention [9]. As well as it was observed that the great majority of the patients who underwent testing don't follow the recommendations from the Ministry of Health, highlighting the precariousness of the assistance offered to mother and child, making even higher the difficulty of incorporating such practices in the health services, a fact that was also reflected in the statements from the professionals involved about the low supply of the examination. However, the tests eased the matter of quick access to the HIV diagnosis, giving immediate support to pregnant women who underwent the process, improving the access to the health service.

The experienced moment allowed us the opportunity of reflection about the importance of making the antiHIV test in the routines of pre-natal appointments, as well as about the challenges that appear during the health service adequacy in order to provide a quality assistance to the population.

Lastly, the action developed sought to aggregate an active learning process in the search for a critical meaning to the live practice, allowing and prioritizing the basic attention as a scope of reference and counter reference in the public health service, enhancing concrete answers to the needs of the public, guaranteeing an adequate installment of the service and strengthening the SUS more and more.

\section{Conclusions}

The participation of professionals in testing is of fundamental importance for the assistance of pregnant women during pre-natal care. However, the implementation of quick tests in the units is new and requires patience and commitment of these professionals in the integration of the service routine tests.

The insertion of healthcare students on the health care service in primary care, through the PRO/PET SaúdeRede Cegonha provides a reorientation of vocational training, as we experience the integration of teaching and service, so that a comprehensive approach to the health-disease process is ensured with emphasis on primary care, increasing the qualifying services of professional tutors, as there is an exchange of experiences, enabling involvement in the academic and professional training opportunities in the way of comprehensive care, attention, and interdisciplinarity.

Thus, the integration of education and service has been a facilitator in the education reorientation process in higher education providing students with a higher experience of multidisciplinary, preparing them for the professional field, providing them with full attention and eliciting a holistic look within the health education field.

\section{References}

[1] Azevedo, A.L.M. and Costa, A. (2010) The Narrow Entrance Door of the Unified Health System (SUS): An Assessment of Access in the Family Health Strategy. Interface-Comunicação, Saúde, Educação, 14, 797-810. http://dx.doi.org/10.1590/S1414-32832010005000029

[2] United Nations Programme on HIV/AIDS (2008) The United Nations and the Response to AIDS in Brazil. United Nations in Brazil, Brasília.

[3] Ministry of Health (BR) (2013) Secretariat of Health Surveillance. Epidemiological Bulletin HIV-AIDS. Ministry of Health, Brasília.

[4] Ministry of Health (BR) (2007) Secretariat of Health Surveillance. Programa Nacional de DST/AIDS. Operational Plan: Vertical Transmission Reduction of HIV and Syphilis. Ministry of Health, Brasília.

[5] Ministry of Health (BR) (2014) Secretariat of Health Surveillance. Vertical Transmission of HIV and Syphilis: Strategies for Reduction and Elimination. Ministry of Health, Brasília.

[6] Ministry of Health (BR) (2008) Ordinance No. 1802 of 26 August 2008. Institutes the Program of Education at Work 
for Health—PET—Health. Official Diary of the Union 27 ago 2008; Seção 1.

[7] Silva, O., Tavares, L.H.L. and Paz, L.C. (2011) The Performances of the Nurse Related to the Rapid Test HIV Diagnosis: A Reflection of Interest in Nursing And Public Health. Enfermagem em Foco, 2, 58-62.

[8] Ministry of Health (BR) (2010) Secretariat of Health Surveillance. Recommendations for Prophylaxis of Vertical Transmission of HIV and Antiretroviral Therapy in Pregnant Women. Ministry of Health, Brasília.

[9] Pereira, M.P. and Nunes, T.R. (2011) Screening for Infection with Human Immunodeficiency Virus at Delivery. Revista Brasileira de Ginecologia e Obstetrícia, 33, 170-175. 